\title{
Using Remote Sensing and Aerial Photos for Groundwater and Surface Water Resources in Jordan Valley, Jordan
}

\author{
Emad Akawwi*
}

\author{
Al- Balqa'Applied University Al-Salt, 19117 Jordan; ejeakawwi@bau.edu.jo, ejeakawwi@gmail.com
}

\begin{abstract}
Objectives: This research is to develop features and maps for using for managing the surface water and groundwater at the lower part of Jordan Valley. Methods: several different maps were created. The surface water map was issued by using the rainfall data. The digital elevation model was built in by using the topographic maps and the aerial-photos; from this digital elevation model a slope map was issued. The drainage network map was issued depending on the digital elevation model and slope maps. The structural map was created by using satellite images and geological map. Findings: The rainfall in the northern and eastern highland parts of the study area classified as good amount but the type of soils is low permeability. The slope is relatively moderately high and the area is highly fractured. But the fractures are filled with a secondary hard material. Then the infiltration to the groundwater is low. Then the surface water flow toward the foot of the Jordan River. The foot of the Jordan River area characterized by flat area with very low slope and the soils is characterized as a moderate permeability. Then the infiltration is relatively high. But the precipitation at this part of the study area is very low. Other findings from this study the drainage network system in the most of study area is high density dentritic. The combination of wadies and major fracture indicates as a higher potential of groundwater storage. Applications: The study is very useful for a developing a surface water and groundwater modeling. Developing also a potential maps for the surface water and groundwater.
\end{abstract}

Keywords: Groundwater, Jordan, Jordan Valley, Remote Sensing, Surface Water

\section{Introduction}

The shortage of water supply has become a main environmental problem in many countries in the world. Because of the demand for water has increased in the last decades with the increase in the population size and due to climate change. This is well pronounced in arid and semiarid regions. Jordan is one of these countries suffered from water shortage and the limited of freshwater resources. These reasons are the main challenges facing the sustainable development in Jordan therefore it is need development and management of its limited fresh water resources. Some of the most important groundwater problems in Jordan are: overexploitation and lowering of its levels in some areas; saltwater intrusion into freshwa- ter aquifers in some of the Jordan Valley regions. Water scientists rely on several geological layers and other structural elements (eg- faults, fractures). However, fracture and fault systems are considered as major elements in groundwater occurrence or discharge in one hand. On the other hand sharp flexures can form a barrier to groundwater flow.

Satellite images provide efficient data and effective method for geological mapping, groundwater and other features. Satellite images data are useful because they provide up-to-date information on the accessibility of an area to be surveyed particularly, concerning, land use, general topography, the presence of surface water and drainage system and etc. The use of remote sensing data allows effective localization of targets and reducing

${ }^{*}$ Author for correspondence 
costs and time. 1 The concept of integrated remote sensing and GIS has proved to be an efficient tool in groundwater studies used Remote Sensing (RS) and Geographic Information Systems (GIS) in the exploration and assessment of groundwater in consolidated and unconsolidated formations in semi-arid regions. ${ }^{2-4}$ In the reported article used aerial photographs, Landsat Thematic Mapper (TM) images and Digital Elevation Models (DEM) for mapping paleodrainage patterns, large depressions, play as and catchments areas. $\underline{\underline{5}}$ These parameters are used for accumulating large amounts of water during flash floods and recharging of freshwater lenses. These data sets were analyzed using GIS to delineate the most favorable areas for the formation of fresh groundwater lenses.

The nature of remote sensing-based groundwater exploration is to describe all possible features, as faults and fractures, connected with localization of groundwater. In the present artice reorted used a remotely sensed surface as indicators of groundwater as alternative of the classical data. ${ }^{6}$ In the reported article checked the use of remote sensing in hydrology but with many limitations. ${ }^{-}$There are several studies utilized the space tools in hydrology, such obtained by the presented articles. $\underline{\underline{8-10}}$ Recently, the reliable procedures to delineate fracture systems are successfully achieved when using space tools, notably the processing of satellite images. Therefore, the identified linear features on satellite images are known as "Lineaments". The detected lineaments, as being verified in the field, are attributed to rock fractures of different scales and types. They proved to have great significance in creating groundwater-transport routes, as well as they influence water input and output from the terrestrial environment. In the referred article used the remote sensing combined with GIS to create recharge potential zones. ${ }^{11}$

Both Remote Sensing (RS) and Geographic Information Systems (GIS) technologies have good potential to rampaging the monitoring and management of vital in area of groundwater resources. GIS is a powerful environment for real time database development. It's capable of managing large amounts of spatially related information, providing the ability to integrate multiple layers of information and drive additional information. Because of advantages of spatial spectral and temporal availability area within short period the remote sensing has become a very rapid and cost effective tool in assessing, monitoring and conserving groundwater recourses. Remote sensing data were used by the article presented order to prepare and analyze drainage and topography to detect the most promising sites for groundwater exploration in an arid basin in Jordan. ${ }^{12}$ In the article reported used the thermal infrared imagery for delineating the submarine groundwater discharge along the Dead Sea shore lines. $\stackrel{13}{ }$ In the presented article used the radon 222 concentrations to approve that there are a connections between the subsurface aquifers and surface water due to the fractures. $\underline{14}$

The objective of this study is to define two major concepts in surface and groundwater. First is the procedure how to determine faults, fractures and lineaments (fracture systems) from satellite images and aerial-photos, and second is to utilize these systems to assess groundwater regime. The other indirect objectives of this research are to developing many features and several different maps for the study area. These features and maps will be used as a base for a surface water and groundwater model of the lower part of Jordan Valley and for developing potential zones of surface water and groundwater.

\section{Study Area}

The study area is the Eastern part of the Jordan Valley and the surroundings. The elongation of Jordan Valley is about $110 \mathrm{~km}$ that extends from the northern corner of the Dead Sea at the south of the study area to the Lake of Tebaries (Sea of Galilee) at the north of the study area is shown in Figure 1. The eastern escarpment of the Jordan Valley can be sub-divided into different terrains or topographic zones. These zones are, the highlands (800 -1000 $\mathrm{m}$ ) above mean sea level (amsl), the escarpment, including the east slope of the valley (reach to 800 $\mathrm{m}$ above sea level), the foothills of the JV, its' elevation is from $-200 \mathrm{~m}$ to the sea level, the rift valley floor, the JV floor is gradually slopes from $220 \mathrm{~m}$ below sea level in the northern part of the study area at Lake Tebaries, then heading southward to the northern corner of the Dead Sea reach to about $436 \mathrm{~m}$ below sea level (in 2016). Stratagraphically the Jordan Valley floor is mainly composed of Lisan formation (form Quaternary age), undifferentiated Neogene formation, talus deposits, fan deposits and terrace deposits underlain by sub basins filled with marine and continental sediments. Geologically the Jordan Valley divided into four sub-basins; Jericho (Shuna) basin at the southern part of the Jordan Valley, Damia basin, Besean basin and Bakura basin at the northern part of the Jordan Valley. Water resources in the Jordan Valley consist of groundwater, surface water, and treated wastewater from 
Amman Zarqa Basin. These waters used for drinking and irrigations.

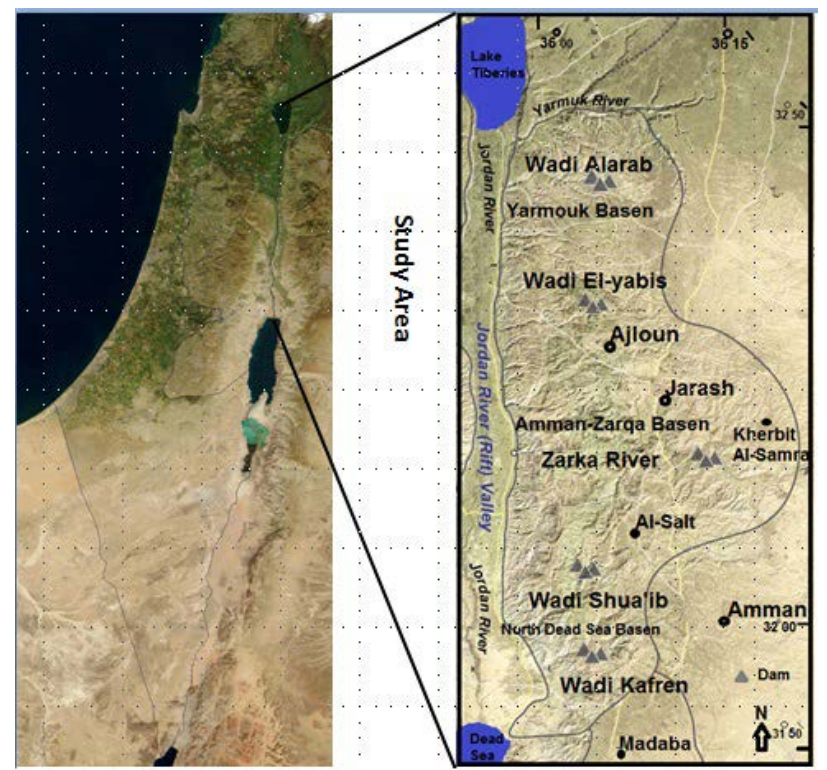

Figure 1. Akawwi: The study area that extend from the lake Tebaries at the north to the northern corner of the Dead Sea at the South of the study area.

\section{Materials and Methods}

In order to assess the impact of the above objectives, suitable images from a range of earth resources satellites and aerial photos were used. The occurrence of the surface water and the groundwater in the Jordan Valley area can be effectively mapped using the integration of thematic maps generated from remotely sensed data, aerial-photos data, topographic and Geological Maps data. These thematic maps were used as an input in a GIS/ArcMap (ESSRI).

\subsection{Precipitation Map}

Rainfall is one of the major sources for groundwater by infiltration or recharging. The high rainfall amounts imply the possibility of high groundwater recharge. In general, the rainfall in the area is characterized by around five months rainy months-from November to March, followed by a seven-month dry season-from April to October. Precipitation falls on the high altitude areas during the wet season is in the form of rain or snow. The precipitation data were obtained from different measurement stations spread in all over Jordan..$^{15}$ These data were input in GIS in order to generate the precipitation map.

\subsection{Soil Map}

The type of soil consider as an important factor on groundwater recharge through infiltration and loss through surface run-off. The type and permeability of soil affect the water holding and infiltrating capacity of that soil. The soil map of the Jordan Valley area was issued by using Landsat Satellite Images (TM) green red and the thermal band. The thermal band of the Landsat TM was used for soil categories through its ability to characterize the clay, organic matter, and iron-oxide content of the soil. The different types of soil depending on the content of organic matters and clay were recognized.

\subsection{Geological Map}

The geological maps of the Jordan Valley were created by using the eight sheets of scale 1:50000 geological maps issued by the presented article each sheet cover a different area. ${ }^{16}$ These sheets of geological maps were registered by using GIS. These maps combined together to get one geological map covers whole Jordan Valley area. The geological formations were digitizing by using the GIS.

\subsection{Structural (Lineaments, Faults, Fractures) Map}

Faults and Lineaments are discontinuous earth's features. They can be identify and extrapolate more easily by using satellite image and Aerial-photos than on the ground. Mapping of the Faults and lineaments were done using false color composite image of 742 (RGB) and each bands were investigating and compared in terms of contrast and band 4 were selected because it shows good contrast by using ENVI software and Geomatics PCI for lineaments extractions. The Geological maps with scale of 1:50000 developed after the referred article and stereo pair of Black and White aerial photos with nominal scale of 1:33000 also supports the lineament and faults mapping. $\frac{16}{}$

\subsection{Digital Elevation Model and Slope Map of Jordan Valley Area}

A Digital Elevation Model (DEM) is a digital file consisting of terrain elevations for ground positions at regularly spaced horizontal intervals. ${ }^{17}$ The DEM of the study area was created by using the topographic maps with scales of 1:25000 with a contour interval $20 \mathrm{~m}$. GPS points where obtained from the field to support the DEM and make it more accurate. The topographic maps where scanned 
and geo-referenced by using the GIS 10 (ESSRI). Then the contour line digitized and interpolated by using Inverse Distance Weighting (IDW) and was modified by kriging methods. The slope map of the study area was issued by using Arc Map GIS. The DEM raster was used as input in GIS then from special analyst tool box-surface-slope the slope map was issued.

\subsection{Drainage Networks Map}

Drainage map of the study area was extracted from the digital elevation model by using the flow direction grid map. The raster image of the surface water flow direction was used to determine the stream network. The DEM as a raster was used as input in Arc Map (ESSRI) - Arc Hydro extension. Then a step by step the drainage network has been issued.

\section{Results and Discussion}

\subsection{Surface Water}

The surface water basins in the Jordan Valley subdivided into the Jordan Valley basins (Yarmouk Basen, AmmanZarqa Basin and North Dead Sea Basin) and the Jordan Valley side wadis basin is shown in Figure 1. The water resources in the North Jordan Valley are Yarmouk River, Lake Tiberias, and Mukheba wells. The Yarmouk River flow to King Abdulla Canal, which is varies significantly yearly which depends on the annual rainfall and on the discharge from upstream that use by Syria. More than $70 \%$ of the Yarmouk Basin located inside Syria to the north. Topographically as well as hydrologically a major anticline, Ajloun acts as the divide for Yarmouk River Basin and the Northern Rift Side catchments. The Amman-Zarqa basin located to the south and east, and the Northern Rift catchments to the west. The climate of the basin is generally lies between a Mediterranean and arid climate. The annual precipitation in Al-Yarmouk Basin varies between more than $500 \mathrm{~mm}$ in the west (Irbid area) and less than $200 \mathrm{~mm}$ in the east (Sama Es Sirhan area). While the annual rain precipitations at the Azraq Amman Basin varies from $100 \mathrm{~mm}$ at Zarqa to about 450 $\mathrm{mm}$ at Salt and Amman as shown in Figure 2.

In addition there are several side wadis distributed along the Jordan valley flow from east to west toward the Jordan River, however, some water from these side wadis is used in the upstream eastern of King Abdulla Canal. In addition, four small dams are built on these wadis along the Jordan Valley area. Al-Karameh dam with a storage capacity of about $52 \mathrm{MCM}$ is the largest dam in the Jordan Valley..$^{18}$ Unfortunately its water is saline and can't be used for irrigation without further treatment. Brackish springs also exist in the valley some of which are desalinated and used for irrigation privately. The volume of As Samra effluent discharged to the Zarqa River. Water in King Talal Dam is released to King Abdulla Canal where it is mixed with the fresh water and used for unrestricted irrigation in the Middle and the southern parts of the Jordan Valley as shown in Figure 3.

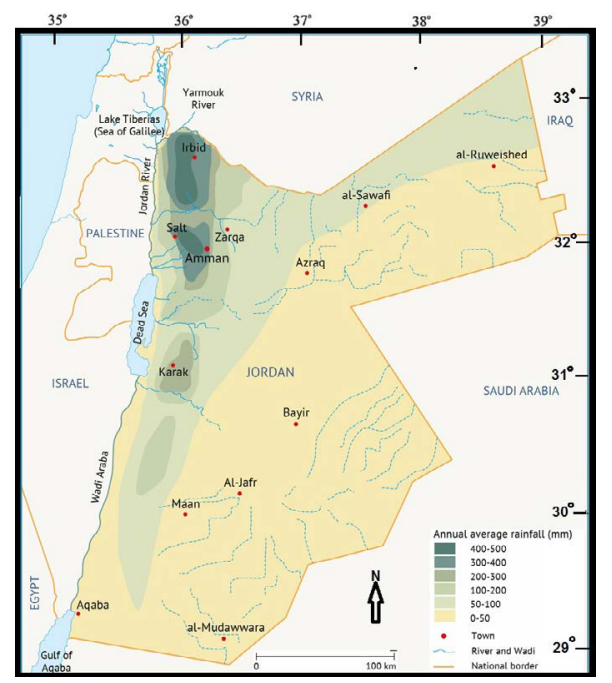

Figure 2. Akawwi: The Rainfall Distribution Contour Map for Jordan (Using Metrological Department Data 2014).

\subsection{Soil in Lower Jordan Valley Area}

The soils consider as one of the most important factor for the surface water and the groundwater. The most important classification in issue of the surface water and the groundwater is the infiltration ability of the soil. Generally the study area is covered with different types of the soils. The most important one is Inceptisols (Xerochrept). This soil classified as mmoderately developed soils, in Jordan mostly red, with clay-rich B-horizon, often rich in primary or secondary calcium carbonate with low infiltration rate. This type of soil covers most of the study area. The other type of soil that present in the study area is Aridisols (Camborthid and Calciorthid). These soils cover the area along and adjacent to the Jordan River at the flat area or an area with very gentle slope classified as Soils with aridic moisture regime, weak soil development, often enrichment of calcium carbonate and/or gypsum or 
other salts. The last type of soil at the study area is Entisols (Torrifluvent, Torriorthent). $\frac{18,19}{19}$ These soils cover very small spots at the Jordan Valley area. These soils classified as Very weakly developed, initial soils, mostly A-C horizons or no horizons, sometimes similar to crushed bedrock, shallow and/or rich in stones or gravel and the infiltration of these soils is very high. Therefore they are very good for the groundwater resources. All of these types of soils are summarized in the Figure 3 which shows the locations of these types of soils.

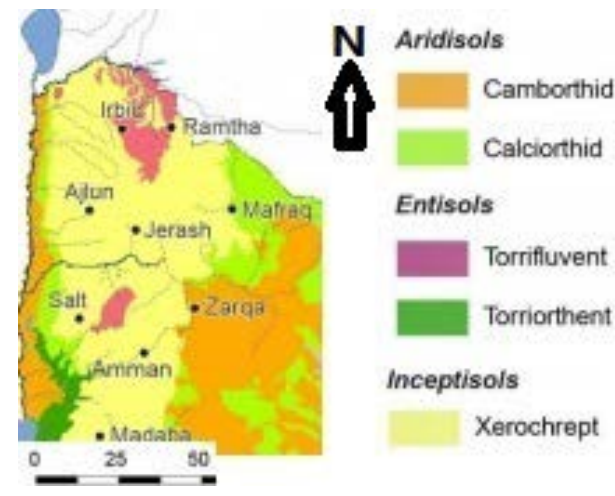

Figure 3. Akawwi: Soils Map Of the study area.

\subsection{Geology of the Jordan Valley}

Rock formations that outcropping within the Yarmouk Basin range from Upper Cretaceous to Eocene ages. These rock formations form two groups, the Ajloun group (A1 to A7 formations) Touronian age overlies by Belqa group (B1 to B5 formations). The Ajloun group consists mainly of marl, marly limestone, and limestone; it is defined clearly in the south and southeastern parts of the basin. This is where the groundwater recharge occurs. The Belqa group generally consists of chalky limestone and chalky marl with interbeded with chert nodules. The most important formation from the hydrology point of view is the B2-A7 Formation. Generally the thickness of these two groups increases toward the north. The eastern parts of Yarmouk Basin are covered by basalts (Quaternary age) overlay the B2 formation.

The outcropping of Amman-Zarqa Basin extends from Lower Cretaceous (except wadi deposits which are Quaternary) to recent age, which is belonging to the Ajlun and Belqa Groups. However, the Kurnub Group (Lower Cretaceous) is usually found at certain depths except where it outcrops in western parts of the study area (Baq'a Valley) along the axis of Suweileh anticline. It consists of multi colour of sandstones interbedded with clay.
The outcropping rocks in the study area mainly consist of Ajlun group (A4-A7) A7 is Wadi Essir formation and Balqa Group (B1 and B2) B2 is Amman silicified limestone. Valleys are generally filled with alluvial deposits of gravel, boulders, and pebbles. The Amman Formation B2 (Santonian - Campanian) consists of cyclic deposits of chalk, phosphate, silicified phosphate, limestone and chert. The shallow aquifer in the Jordan Valley area is A7/ B2 formation. Figure 4 shows the geological map with the geological formations for Jordan Valley area

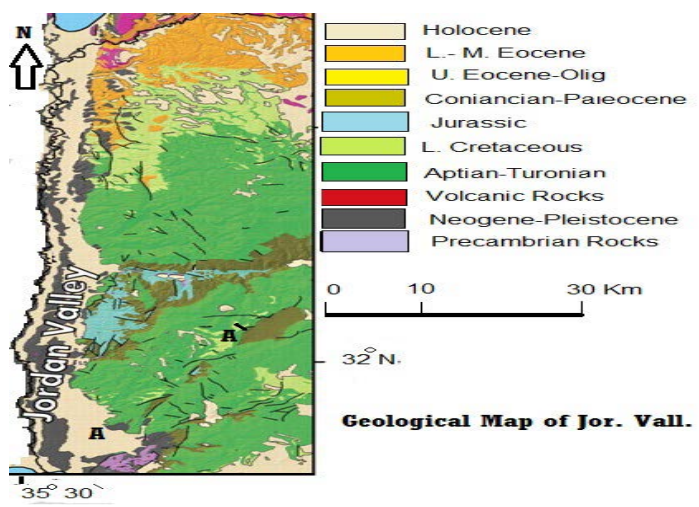

Figure 4. Akawwi: Geological Map shows distribution of the rock formations for the Jordan Valley.

The A-A'cross section the southern part of the study are shown in Figure 5 this cross section shows that the shallow aquifer is missing to the south east part of the study area. This aquifer is cropping out at the southern west of the study area. Therefore the aquifer at this part of the study area is rechargeable but the precipitation is less than $100 \mathrm{~mm} /$ year.

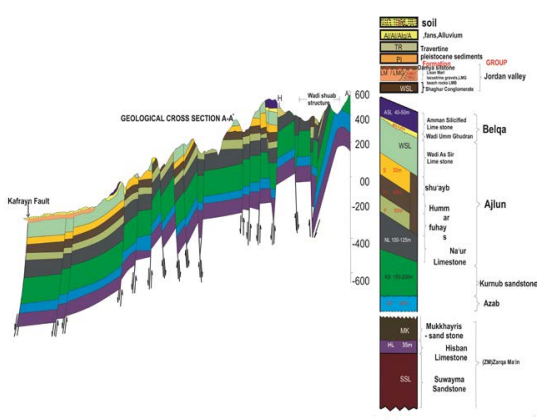

Figure 5. Akawwi: Geological cross-section at the southern part of the study area.

\subsection{Elevation of the Jordan Valley Area}

The digital elevation model of the study area shows that the elevations of the Jordan valley area range from $400 \mathrm{~m}$ 
below main sea level (bmsl) at the base of the Jordan level to about $1260 \mathrm{~m}$ above main sea level (amsl) at the Ajloun city. This big difference of elevation is within a $25 \mathrm{~km}$ horizontal distance. Figure 5 shows the digital elevation model of the study area. This digital elevation model was compared with the digital elevation model that issued by the presented article. ${ }^{20}$ He used other method (i.e. ground control points GPS). Both digital elevation models are matching. Figure 6 shows the digital elevation model of the Jordan Valley.

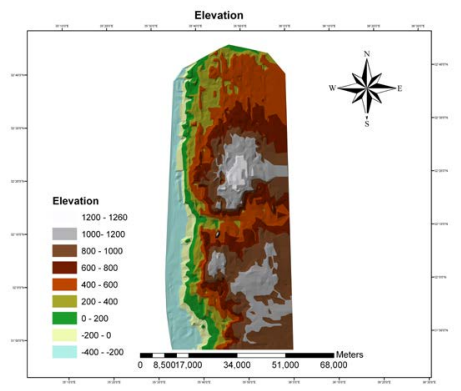

Figure 6. Akawwi: the digital elevation model of the Jordan Valley area.

\subsection{Slope of the Jordan Valley Area}

The slope of the Jordan Valley area is range from a flat area with slope 1.5 degrees to about 65-70 degrees. At the top of the mountainous areas at Ajloun highlands and other highlands the slope is about 70 degrees. This areas slope toward the Jordan River to the west of the study area. This steep slope is decreasing gradually toward the Jordan River to reach about 1.5 degrees at the area closed to the Jordan River coast (i.e. the slope at the Jordan River wadies basement). Generally the slope of the most of the study area ranges between 1.5 degree and 7.5 degrees. Figure 7 identifies the slope map of the Jordan Valley area and surrounding mountainous area. This map was compared with slope map that issued by the article presented. ${ }^{20}$ which was created by using digital elevation model which was issued by using Ground Control Points (GPS). The slope map in this study and the slope map was issued by the referred article is coinciding. ${ }^{20}$

\subsection{Hydrology and Drainage Systems of the Study Area}

The drainage density depends on the slope, nature and attitude of bedrocks and the existing regional and local fracture patterns. They reflect the lithology and structure of a given area and can be of great value for groundwater resources evaluation. Drainage density is approached in two ways with respect to groundwater: the drainage pattern and the drainage density.

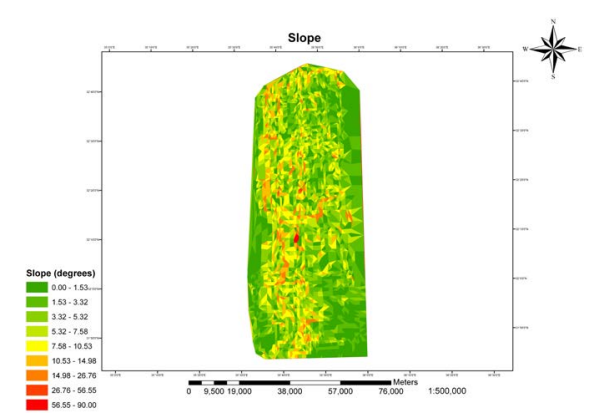

Figure 7. Akawwi: slope map of the study area.

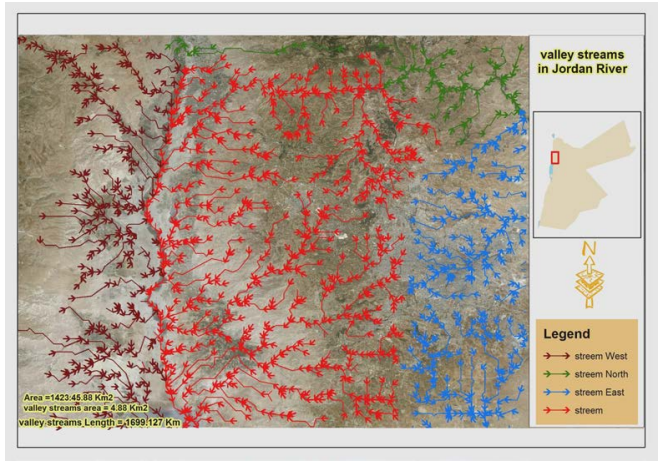

Figure 8. Akawwi: the drainage systems network of the study area.

In spite of a high rainfall of the Yarmouk Basin, its watershed is characterized by low density dentritic drainage systems. Due to most of the plains are flat and are covered by fertile soils. Therefore the area considered as an important recharge for the groundwater due to a high permeability and a high infiltration rate because of the underlying rocks which is basalt and highly fractures limestone. While closing to the Jordan Valley and the southern part of the Yarmouk the drainage system become denser and deeper because of the type of soils and the underlain rocks (marl and marly limestone) which are characterized as a low permeable and low infiltration then the surface runoff increase and subsurface runoff decrease (i.e. the drainage system in this area is high density dentritic). Figure 8 shows the drainage systems in the study area.

The drainage systems map show that the most of the drainage types is dentratic systems. These types of drain- 
age indicate that the outcrop rocks are soft to medium hard rock as clay or clayey limestone. This indicates that in view of the rock types the infiltration into the groundwater will be low and increase the speed of the flow of the surface water toward the Jordan Valley.

\subsection{Hydrogeology and Groundwater of the Jordan Valley}

Ground water in the Jordan Valley is present in three aquifers termed the shallow, upper sub, and deep aquifers. The aquifer systems of Jordan Valley are either related to the Ajloun or to the Belqa Groups or Kurnub sandstone. The upper aquifers (shallow aquifer) consist of two formations: the B4/B5 aquifer from Plio-Pleistocene ages. It consists of chalky limestone and marly limestone with chert nodules: it is a shallow thin rechargeable aquifer.

The A7/ B1- B2 aquifer is in the uppermost unit of the Ajloun group and the lower ones of Belqa Group (Upper Cenomanian and Turonian ages). They consist of the Wadi Sir Limestone Formation (A7), the Ruseifeh Formation (Bl), and the Amman Silicified Limestone (B2). This aquifer is primarily limestone, dolomitic limestone, and chert. Its recharge derives from the nearby Ajloun Mountains and local catchment areas, as well as from ground water flow from the Syrian territories into Jordan. The deep confined aquifer of the Lower Cenomamian age. A7-B2 has a large and continuous extent, and a relatively high permeability. It receives the highest amount of modern recharge. It is considered to be the principal source of fresh water for domestic as well as for irrigated agriculture in the Jordan Valley area.

\subsection{Faults and Lineaments along the Jordan Valley}

Faults and lineaments are discontinuous earth's features that can be more easily identified and extrapolated on satellite image and aerial-photos than on the ground. These features are mapped as lineaments influencing the occurrence of groundwater acting as conduits and/or reservoirs. The faults can be either a conductor or a barrier depending on the intensity of fracturing and if these fractures are opened or filled with secondary materials. The length and distance from aquifers of faults is also an important parameter in controlling regional subsurface water flow rather than local movement. The majority of the faults have small thickness and length that shows their influence is on specific locations of groundwater movement rather than regional one. The structures, locations, and orientations with respect to groundwater flow are very important. The geological structures that affecting groundwater movement is Sweilih Anticline: The axis of this anticline strikes NE-SW. Erosion in this anticline has exposed the Kurnub Sandstone Aquifer in Ain el Basha and Baqa regions north of Sweilih. The rainfall in these areas relatively high reache Kurnub as direct or indirect. The second one is Amman- Zarqa Syncline: The axis of this syncline strikes NE-SW. It extends from the southwestern side of Greater Amman to about $6.5 \mathrm{~km}$ southeast of Zarqa city. The syncline is about $30 \mathrm{~km}$ long and 12 $\mathrm{km}$ wide. This synclinal zone is the highest potential area in the Hummar aquifer. The Third geological structure is Amman- Zarqa Monoclinal Flexure: The axis of this structure is parallel to the Amman-Zarqa syncline. It is to the southeast of the synclinal axis. This monoclinal flexure and associated faulting form a hydraulic barrier to the eastward movement of water within the Hummar (A4) aquifer.

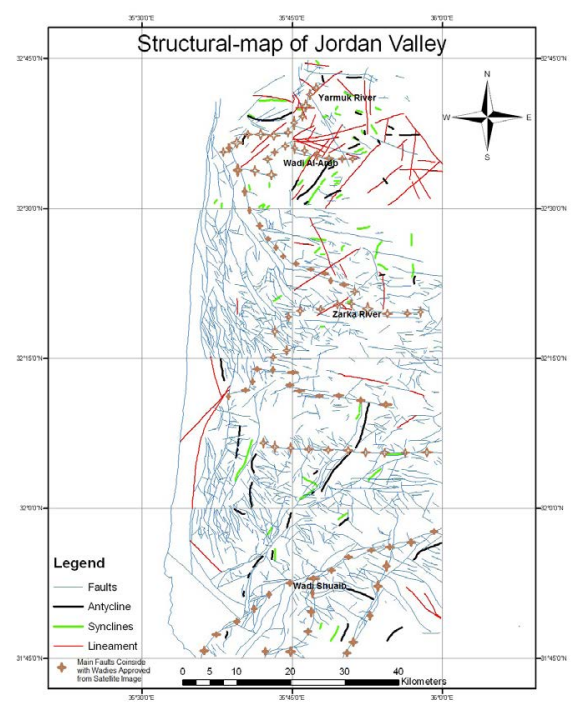

Figure 9. Akawwi: the structural (Lineament and Faults) map.

Figure 9 shows the structure map of the study area that was issued from the satellite image and the geological maps 1: 50,000 scale. This map shows that the area has numerous amounts of lineaments, main and minor faults and fractures. These structures increase the infiltration of the surface water into the groundwater. In the other hand 
they increase the flow of the groundwater toward the Jordan Valley. This map shows the faults, lineaments and the main fractures. There are many faults coincide with the main wadies and surface water drainages. These faults denoted as a stars star shape.

\section{Conclusion}

Slope plays an important role in influencing the recharge of groundwater depending on the degree of gradient. The study area lies topographically at higher elevation and having flat to dissected sloppy morphology. Flat areas are capable of holding the rainfall and facilitate recharge to groundwater as compared to steep slope area where water moves as runoff quickly. The slope map shows that the most of the study area is moderate slope. It ranges between 5 and 10 degrees. But this area covered with type of soil that is identify as low permeable therefore the groundwater recharge at this area will be very low. As results the surface run off will be high while the subsurface runoff will be very low. Therefore a part of water that is coming from rainfall at this area will drain to the Jordan River and other part will evaporate. The area located at the foot of the Jordan valley identify as flat area with very low slope (i.e 1-3 degrees) and covered with type of soil with high permeable. Therefore the recharge for groundwater will be high and surface runoff will be high. But the rainfall at this area is very low and the evaporation is very high. As final conclusion for all over the study area the recharge for the groundwater is low and surface runoff will be high.

\section{Acknowledgments}

The Author expresses his high appreciation for the Al-Balqa Applied University for accepting sabbatical leave for one year. The author also thanks Philadelphia University for accepting to spend sabbatical year at the university.

\section{References}

1. Rokos D, Mavrantza R, Vamvoukakis K, St-Seymour, Kouli M, Karfakis I, Denes G. Localization of ore alteration zoning for the detection of epithermal gold by integration of remote sensing and geochemical techniques. Proceedings of the Fourteenth International Conference on Applied Geologic Remote Sensing. Las Vegas Nevada; 2000. p. 161-8.
2. Saraf, Chaudhary PR. Integrated Remote sensing and Geographic Information System for groundwater exploration and Identification of artificial recharge sites. International Journal of Remote Sensing. 1998; 19(10):1825-45. Crossref

3. Khan M. Use of Remote sensing and Geographic Information System in the delineation and characterization of groundwater prospect zones. Journal of Indian Society Remote Sensing. 2002; 30(3):131-41. Crossref

4. Jasmin I, Mallikarjuna P. Satellite-based remote sensing and geographic information systems and their application in the assessment of groundwater potential with particular reference to India. Hydrogeol Journal. 2011 Jun; 19(4):72940. Crossref

5. Kwarteng AY. Utilization of remote sensing and GIS for groundwater exploration in Kuwait. In: Sherif, Singh, Al-Rashed editors. Groundwater hydrology. Balkema Publication. Netherlands; 2002. p. 157-78.

6. Elbeih S. An overview of integrated remote sensing and GIS for groundwater mapping in Egypt. Ain Shams Engineering Journal. 2015; 6:1-15. Crossref

7. Rango A. Application of remote sensing methods to hydrology and water resources. Hydrology Science Journal. 1994; 39:309-19. Crossref

8. El-Baz F, Himida I. Groundwater potential of the Sinai Peninsula, Egypt. Project Summary. AID; Cairo. 1995. p. 18.

9. Teeuw R. Groundwater exploration using remote sensing and a low-cost geographic information system. Hydrogeology Journal. 1995; 3(3):21-30. Crossref

10. Shaban A, Khawlie M, Abdallah C. Use of remote sensing and GIS to determine recharge potential zones: the case of occidental Lebanon. Hydrogeology Journal. 2006; 14(4):433-43. Crossref

11. Akawwi E, Al-Zoubi A, Kakish M, Koehn F, Sauter M. Using Thermal Infrared Imagery (TIR) for Illustrating the Submarine Groundwater Discharge into the Eastern Shoreline of the Dead Sea - Jordan. American Journal of Environmental Sciences. 2008; 4(6):693-700. Crossref

12. Solomon S, Quiel F. Groundwater study using remote sensing and geographic information systems (GIS) in the central highlands of Eritrea. Hydrogeology Journal. 2006; 14(5):729-41. Crossref

13. Al-Bakri J, Al-Jahmany Y. Application of GIS and Remote Sensing to Groundwater Exploration in Al-Wala Basin in Jordan. Journal of Water Resource and Protection. 2013; 5(10):962-71. Crossref

14. Akawwi E. Radon-222 concentrations in the groundwater along the eastern Jordan rift, Journal of Applied Sciences. 2014; 14(4):309-16. Crossref

15. Meteorological Department, Amman Jordan. Internal Reports; 2005-2014. 
16. Natural Resources Authority. Geological Surveying Department. Amman; Jordan. Internal Reports.

17. USGS. Digital Elevation Models: USGS Digital Elevation Model Information. Rocky Mountain mapping Center. Available from: http://rmmcweb.cr.usgs.gov/elevation/ dpi_dem.html. Date Accessed: 14/06/2011.

18. Jordan Valley Authority (JVA); Amman. Jordan Internal Report; 2005-2014.
19. Taimeh A. Vertisols in the Southeastern Mediterranean Region Management of Verisols for Improved Agricultural Production. Proceedings An IBSRAM Inaugural Workshop; India; 1985 Feb 18-22. p. 68-77.

20. Akawwi E. Geomorphology using Geographic information System and Globel Mapper. American Journal of Environmental Sciences. 2013; 9(5):398-409. Crossref 